\title{
SCIENTIFIC REPORTS

\section{OPEN Glaucony authigenesis, maturity and alteration in the Weddell Sea: An indicator of paleoenvironmental conditions before the onset of Antarctic glaciation}

\author{
Adrián López-Quirós $\mathbb{1}^{1}$, Carlota Escutia ${ }^{1}{ }^{1}$, Antonio Sánchez-Navas ${ }^{2}$, Fernando Nieto ${ }^{2}$, \\ Antonio Garcia-Casco $\mathbb{D}^{2}$, Agustín Martín-Algarra $\mathbb{B}^{3}$, Dimitris Evangelinos $\mathbb{B}^{1}$ \& \\ Ariadna Salabarnada $\mathbb{1}^{1}$
}

Three types of glaucony grains were identified in the late Eocene ( $35.5-34.1 \mathrm{Ma})$ sediments from Ocean Drilling Program (ODP) Hole 696B in the northwestern Weddell Sea (Antarctica). The grains are $\mathrm{K}_{2} \mathrm{O}$-rich $(\sim 7 \mathrm{wt} \%)$ and formed by smectite-poor interstratified $\sim 10 \AA$ glauconite-smectite with flaky/ rosette-shaped surface nanostructures. Two glaucony types reflect an evolved (types 1 and 2 glaucony; less mature to mature) stage and long term glauconitization, attesting to the glaucony grains being formed in situ, whereas the third type (type 3 glaucony) shows evidences of alteration and reworking from nearby areas. Conditions for the glaucony authigenesis occurred in an open-shelf environment deeper than $50 \mathrm{~m}$, under sub-oxic conditions near the sediment-water interface. These environmental conditions were triggered by low sedimentation rates and recurrent winnowing action by bottomcurrents, leading to stratigraphic condensation. The condensed glaucony-bearing section provides an overview of continuous sea-level rise conditions pre-dating the onset of Antarctic glaciation during the Eocene-Oligocene transition. Sediment burial, drop of $\mathrm{O}_{2}$ levels, and ongoing reducing (postoxic to sulphidic) conditions at Hole 696B, resulting in iron-sulphide precipitation, were a key limiting factor for the glauconitization by sequestration of $\mathrm{Fe}^{2+}$.

Glauconite is the iron-potassium hydrous phyllosilicate mineral typical of the glaucony green marine clay facies, which also includes Fe-rich, 2:1 dioctahedral specimens with expandable layers of randomly interstratified glauconite-smectite ${ }^{1}$. The term glaucony was defined first by Odin and Létolle ${ }^{2}$ for marine green sediments formed by mixed layer glauconite-smectite minerals, which differ from the nonexpanding end-member glauconitic mica (i.e. the true glauconite mineral). Glaucony is commonly reported in low-latitude, shallow-marine settings at water depths $<500 \mathrm{~m}$, temperatures below $15^{\circ} \mathrm{C}$, and under sub-oxic, partially reducing conditions $s^{3}$. It is typically associated with low sedimentation rates and condensed intervals ${ }^{3}$. However, glaucony has also been reported in deep-sea $(>2000 \mathrm{~m})$, low-temperature $\left(3-6^{\circ} \mathrm{C}\right)$ environments ${ }^{4-6}$, and in very shallow marine, estuarine $^{7-9}$ and paleosol ${ }^{9}$ settings. Most of the aforementioned settings share several post-depositional physicochemical conditions: (1) low accumulation rates of detrital sediment, (2) long residence times $\left(10^{3}-10^{6}\right.$ years for ancient records ${ }^{3}$, and alternatively $<10^{4}$ years for recent records ${ }^{10}$ ) of the detrital grains near to the sediment-water interface, (3) granular substratum (siliciclastic or carbonatic; including the muddy filling inside the cavities of carbonate bioclasts) with high permeability and porosity, (4) redox potential (Eh) $\sim 0 \mathrm{mV}$, (5) seawater $\mathrm{pH} 7-8$, and (6) organic matter-rich, semiconfined micro-environments. In summary, glaucony is a sensitive proxy of low sedimentation rates in the marine realm and constitutes a powerful tool for sedimentological and sequence stratigraphic interpretations, due to its association with well-defined trends of sea-level change ${ }^{11,12}$.

${ }^{1}$ Instituto Andaluz de Ciencias de la Tierra, CSIC-Universidad de Granada, Avda. las Palmeras 4, 18100, Armilla, Granada, Spain. ${ }^{2}$ Department of Mineralogy and Petrology, University of Granada, 18071, Granada, Spain. ${ }^{3}$ Department of Stratigraphy and Paleontology, University of Granada, 18071, Granada, Spain. Correspondence and requests for materials should be addressed to A.L.-Q. (email: alquiros@iact.ugr-csic.es) 


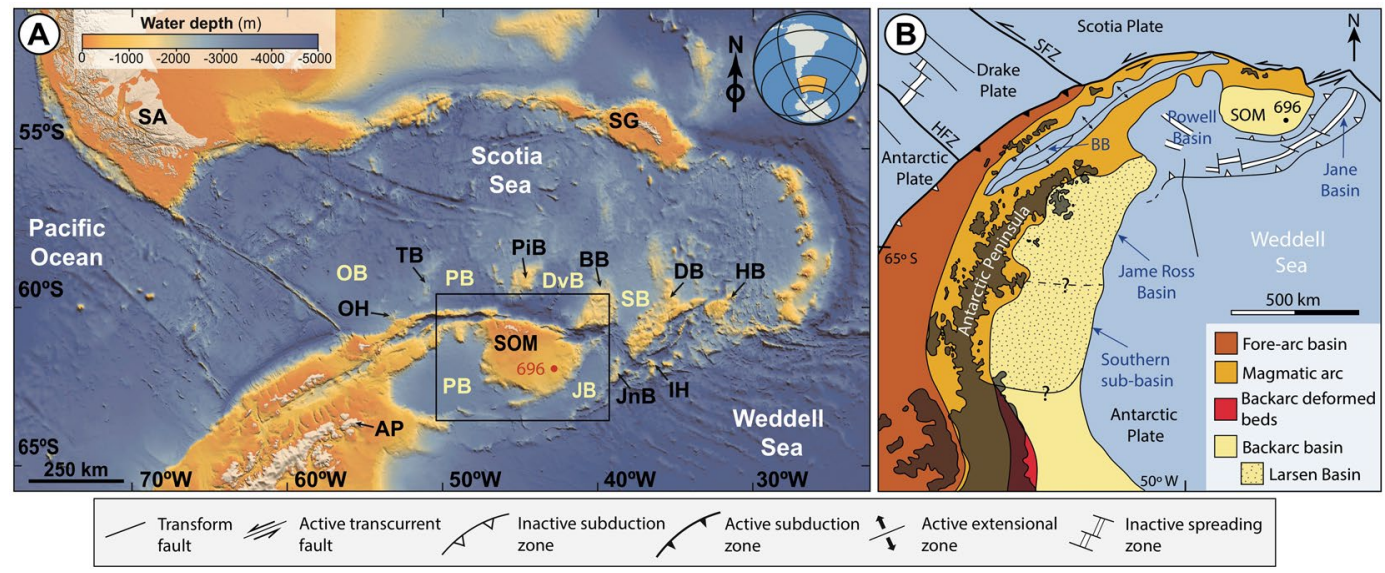

Figure 1. Geological setting of the Drake-Passage Scotia Sea region. (A) Simplified bathymetry map derived from GEBCO, showing the small basins connecting the Weddell Sea with the Scotia Sea. The squared area indicates the study area (see detailed map in Supplementary Fig. S1A). OB: Ona Basin; OH: Ona High; TB: Terror Bank; PB: Protector Basin; PiB: Pirie Bank; DvB: Dove Basin; BB: Bruce Bank; SB: Scan Basin; DB: Dove Bank; PB: Powell Basin; JB: Jane Basin; JnB: Jane Bank. (B) Geotectonic sketch map with lithotectonic units superimposed for the northern Antarctic Peninsula and the South Orkney Microcontinent region. Lithotectonic units displayed in the sketch map are from Elliot $^{63}$.

Glaucony authigenesis in Antarctica has received little attention to date when compared with other mid- to low-latitude Cenozoic to present glaucony records ${ }^{13}$. Cenozoic glaucony-bearing facies have been widely reported in Antarctica and the Southern Ocean (e.g. Tasman Region ${ }^{14}$; Falkland Plateau ${ }^{15}$; Seymour Island ${ }^{16}$; South Orkney Microcontinent $(\mathrm{SOM})^{17}$; Great Australian Bight ${ }^{18}$; Otway Basin ${ }^{19}$; Supplementary Fig. S1). In spite of all these reported occurrences, the genesis, depositional setting control and paleoenvironmental implications of glaucony in these Antarctic regions are loosely constrained. This information, is however relevant because the occurrence of glaucony around the Antarctic margin has been noted in late Eocene sedimentary sequences ${ }^{20}$. Antarctic glaucony deposits thus provide an opportunity to study the poorly-understood paleoenvironmental conditions prior to one of the major climatic transitions in the Cenozoic, the Eocene-Oligocene transition (EOT, 34-33.6 Ma). The EOT is marked by a rapid increase in benthic foraminifer $\delta^{18} \mathrm{O}$ values ${ }^{21}$ involving cooling and the growth of a continent-wide Antarctic ice sheet by the earliest Oligocene (oxygen isotope event Oi-1, 33.6 Ma) ${ }^{22}$.

Previous work suggests that the initial deepening of the seaway at the EOT led to the isolation of the SOM from the Antarctic Peninsula ${ }^{17}$. Based on geophysical studies of the region, the western and southern-to-southeastern margins of the SOM result from continental rifting and subsequent opening of Powell and Jane basins during the Cenozoic ${ }^{23}$ (Fig. 1). Jane basin is a backarc basin related to subduction of the Weddell oceanic lithosphere below the south and southeastern margins of the $\mathrm{SOM}^{24}$. Furthermore, hydrothermal circulation associated with the Powell Ridge spreading axis has been reported ${ }^{25,26}$. Whilst the geodynamic setting of the SOM is fairly well constrained $^{23}$ (for details see Supplementary Information), the timing of events and the paleoenvironmental conditions throughout the Cenozoic remain obscure.

In this contribution we describe, for the first time in the Southern Ocean, a significant Cenozoic (late Eocene) glauconitization event in the vicinity of the SOM shelf (Site $696^{17}$; Fig. 1 and Supplementary Fig. S2A), utilizing textural, mineralogical and geochemical analyses. Based on this multi-proxy approach, we reconstruct the paleoenvironmental conditions, including water depth changes, sediment-water interface (before burial) oxygenation conditions, and the influence of post-depositional alterations on authigenic mature glaucony. Altogether, this information provides an important window into the paleoenvironmental conditions prevailing in this Antarctic Peninsula-SOM region before major ice sheet advance during the EOT.

\section{Material and Methods}

The ODP Leg 113, Hole 696B (latitude: $61^{\circ} 50.959^{\prime}$ S, longitude: $42^{\circ} 55.996^{\prime} \mathrm{W}$ ) was drilled on the SOM in the northwestern Weddell Sea, at $650 \mathrm{~m}$ water depth (Fig. 1 and Supplementary Fig. S2A). The recovered sedimentary column (645.6-0 mbsf) consists of three main sediment types (terrigenous, diatomaceous and hemipelagic) spanning the late Eocene to the Quaternary ${ }^{17,27}$ (see Supplementary Information; Supplementary Fig. S2B). Based on dinocyst stratigraphy, Houben et al..$^{28}$ determined the depth of sediments recording the EOT and the Oi-1 event from 571.5 mbsf to 569.1 mbsf.

This study focuses on sediments containing high amounts of glaucony grains recovered between 606.9569.7 mbsf (Subunit VIIC in Barker et al. ${ }^{17}$; Supplementary Fig. S2B) therefore predating the EOT (late Eocene 35.5-34.1 Ma), based on the existing age model (Supplementary Information and Supplementary Fig. S2B). Glaucony-bearing samples were selected from different stratigraphic positions throughout the poorly investigated glauconitic packstone facies (Cores 57R-56R; Supplementary Fig. S2C), in order to study potential textural and compositional differences between the glaucony grains. Six thin sections, about $30 \mu \mathrm{m}$ thick, were prepared by epoxy impregnation in order to fill the pores and consolidate the poorly lithified glauconitic packstone samples 
selected from cores (Supplementary Fig. S2C). In addition, glaucony grains were extracted from the whole rock core samples after sieving fractions of $125-250 \mu \mathrm{m}$ and $250-500 \mu \mathrm{m}$. The coarse sediment fractions were later separated by universal electromagnetic separator UMC-1. Purified glaucony grains were further separated from diagenetic complex growths and aggregates along with other sediment grains under the binocular microscope.

Isolated glaucony grains were studied first under binocular microscope for morphological characterization (see Supplementary Fig. S4B,C). In addition, the textures of the glaucony-bearing packstone facies and of the isolated glaucony grains were examined under petrographic and scanning- and transmission-electron microscope (Fig. 2; Supplementary Figs S3D, S4, S5, S6A). During the petrographic study, several photomicrographs of the glaucony-bearing facies were taken with an OLYMPUS DP20 camera connected to a petrographic OLYMPUS BX60 microscope and captured with the OLYMPUS DP image-management software (Instituto Andaluz de Ciencias de la Tierra, CSIC-UGR). Back-scattered electron (BSE) and secondary electron (SE) images of the glaucony-bearing facies and isolated glaucony grains were obtained with an environmental scanning electron microscope (ESEM) FEI Quanta 400 (CIC, University of Granada). High-resolution transmission electron microscopy (HRTEM) photomicrographs were obtained with a Titan instrument with XFEG emission gun, spherical aberration corrector and HAADF detector, working at $300 \mathrm{kV}$, with a resolution of $0.8 \AA \AA$ in the HRTEM mode and $2 \AA$ in the scanning transmission electron microscopy (STEM) mode (CIC, University of Granada). Selected-area electron diffraction (SAED) patterns were acquired for glaucony and other authigenic mineral packets with the same instrument.

$\mathrm{X}$-ray-diffraction (XRD) diagrams from powder glaucony grain concentrates (reduced in size with an agate mortar) and oriented aggregates of the $<2 \mu \mathrm{m}$ fraction treated with ethylene glycol, were recorded using a PANalytical X'Pert Pro diffractometer (CuK $\alpha$ radiation, $45 \mathrm{kV}, 40 \mathrm{~mA}$ ) equipped with an X'Celerator solid-state linear detector (University of Granada). Data were collected for $10 \mathrm{sec}$ in $0.008^{\circ} 2 \theta$ steps. In the case of superposed peaks, the identification of phases and the measurement of intensities of each individual peak were carried out with the help of decomposition routines included in the HighScore software. Qualitative elemental analyses were also obtained through the aforementioned ESEM FEI Quanta 400 (CIC, University of Granada), equipped with an energy-dispersive X-ray spectroscopy system (EDX).

Electron probe microanalysis (EPMA) of the main glaucony-forming elements was carried out with a CAMECA SX100 automated electron microprobe (CIC, University of Granada) in the wavelength dispersive mode under the following conditions: acceleration voltage $15 \mathrm{kV}$, probe current $15 \mathrm{nA}$, and an electron beam diameter $5 \mu \mathrm{m}$ allowing point-by-point element determination. In addition, elemental XR images were obtained with the same CAMECA SX100 instrument operated at $20 \mathrm{kV}$ and $205 \mathrm{nA}$ beam current, with step (pixel) size of $2 \mu \mathrm{m}$ and counting time of $45 \mathrm{~ms}$. The images were processed with Imager software (R. L. Torres-Roldán \& A. García-Casco, unpublished) and consist of the XR signals of K $\alpha$ lines of the elements (colour-coded; expressed in counts) and with voids, polish defects, and all other mineral phases masked out, overlain onto a grey-scale base-layer calculated with the expression $\sum$ [(counts/nA per s)i.Ai], (where A is atomic number, and i is $\mathrm{Si}$, Ti, $\mathrm{Al}, \mathrm{Fe}, \mathrm{Mn}, \mathrm{Mg}, \mathrm{Ca}, \mathrm{Ba}, \mathrm{Na}, \mathrm{K}, \mathrm{P}, \mathrm{S}$ and $\mathrm{O}$ ), which contains the basic textural information of the scanned areas.

The same powder used for the XRD analyses was also used for the spectrometric study of color. The coexistence of both $\mathrm{Fe}^{2+}$ and $\mathrm{Fe}^{3+}$ in the structure of silicate minerals is responsible for the occurrence of light absorption that affects their colour ${ }^{29}$. Diffuse reflectance spectra in the ultraviolet - visible - near infrared (UV-VIS-NIR) were recorded from powder samples at room temperature on a Varian Cary 5E UV-VIS-NIR spectrophotometer (200-2000 nm) (CIC, University of Granada).

\section{Results}

Green-clay authigenesis within the late Eocene glauconitic packstone facies at ODP Hole 696B (Supplementary Figs S2B-C, S3A-E, S4A), has occurred mainly by the transformation of pellets (glauconitized grains of 125-500 $\mu \mathrm{m}$; Fig. 2A,B; Supplementary Figs S4, S5) set in sandy to silty smectite-rich, mixed terrigenous-carbonatic sediments (Supplementary Fig. S3A-E). Besides siliceous biogenous and authigenic components, the major mineral components found into clay size fractions are quartz, alkali feldspar and clay minerals (Supplementary Fig. S3B). Previous studies ${ }^{17,30}$ identified and quantified these clay minerals as smectite (common to exclusive: $>70 \%$ ) and illite (rare to abundant: $<20 \%$ ), associated with sporadic chlorite and kaolinite (rare to common: $\sim 10 \%$ ). In addition, we observe very rare dark green, oriented microcrystalline glauconitized mineral (mica)-grains with high birefringence and parallel cleavage (accordion-like green grains: Fig. 2C; Supplementary Fig. S4B). Three population types of glaucony grains have been distinguished in the sediments under study: Type 1 glaucony is formed by rounded olive green grains without cracks (Fig. 2A,D; Supplementary Fig. S4B,C), with rough surfaces with low packing size/density lamellar-flaky nanostructure. Type 1 glaucony often preserve ill-defined globules and caterpillar nanostructures ${ }^{31}$. These nanostructures most resemble bacterial threads and coccoid-like forms (Fig. 2E-H; Supplementary Fig. S4D) similar to those described in other studies ${ }^{11,32}$, but are also comparable with those of silica microtexture surfaces ${ }^{33}$. These grains show internal spotty to flaky texture in section, as shown by BSE images (Fig. 2D; Supplementary Fig. S5E) and by plain-polarized light images (Supplementary Fig. S5A-C). Type 2 glaucony is made of rounded mammillated to lobate (cerebroid), dark green grains with smooth surfaces with flaky honeycombed nanostructure (Fig. 2A,I; Supplementary Fig. S4F) and often cracked at the margins (Supplementary Figs S4C, S5C). Type 3 glaucony shows brownish-greenish colours (Fig. 2B; Supplementary Fig. S5D) and sub-angular morphology, although cerebroid grains and grain fragments similar to type 2 glaucony are also common. These grains are frequently cracked, show smooth, uniform internal structure in BSE images and display gradual change from darker (brownish) to lighter (greenish) colour from rims to cores and, especially, along cracks (Fig. 2D).

Other authigenic minerals present in the matrix between glaucony grains include the following, in addition to zeolite already described by Barker et al. ${ }^{17}$ : (a) pyrite as framboidal aggregates and crystalline replacements of 

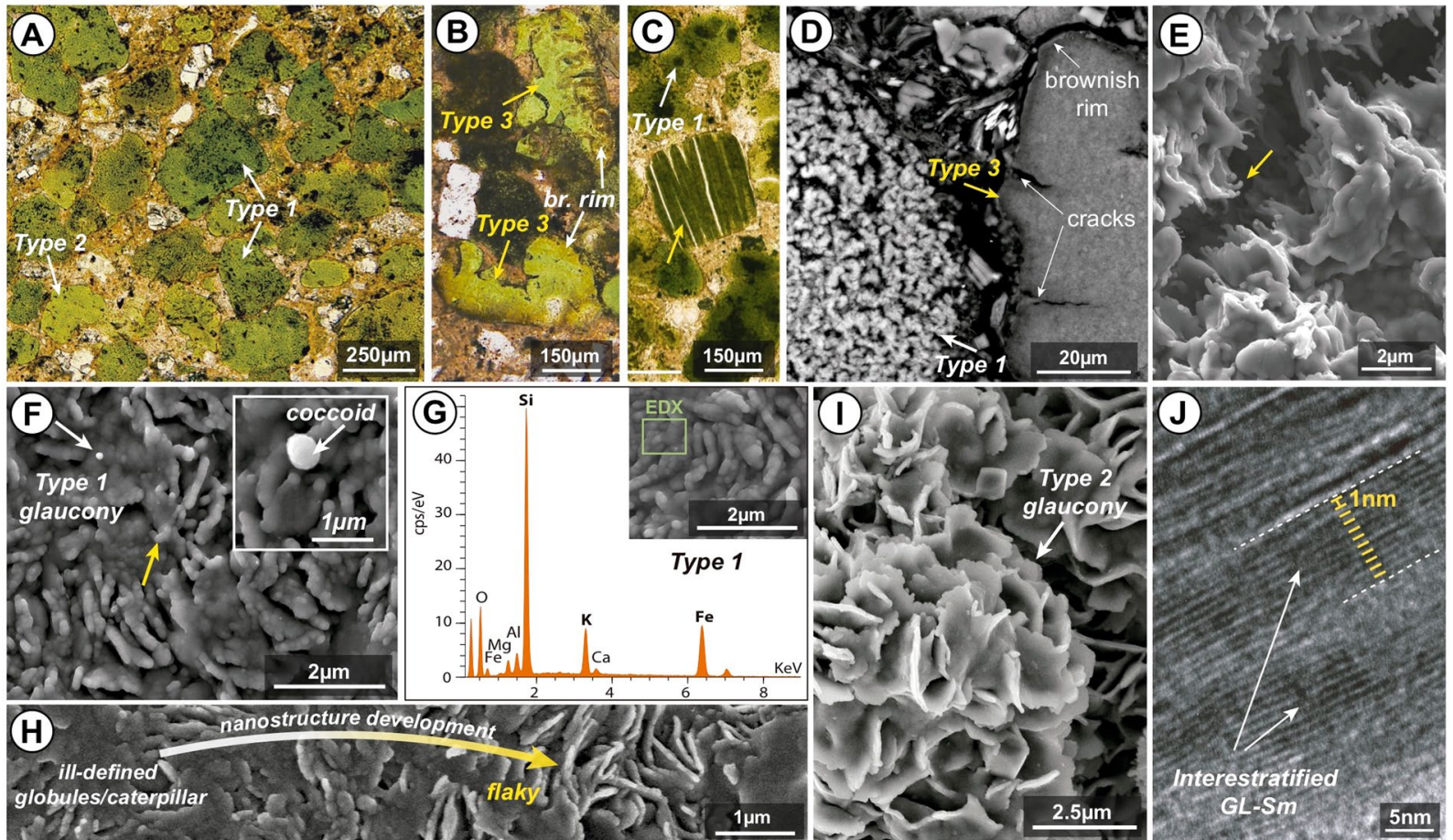

Figure 2. Glauconitic packstone facies. (A,B) Plain-polarized light (PPL) photomicrographs of glaucony grains of types 1,2 and 3. (C) PPL photomicrograph of a glauconitized mineral (mica)-grain (yellow arrow). (D) SEM photomicrograph (BSE) showing the spotty flaky texture in section of a type 1 glaucony grain (white arrow) and the smooth interior of type 3 glaucony (yellow arrow). Note cracks and poorly altered rims associated with type 3 glaucony. (E,F) SEM photomicrographs (SE) showing the nanostructure of the surface of type 1 glaucony, with probable bacterial threads (ill-defined globules/caterpillar structures; yellow arrow) and coccoid-like forms (white arrows). (G) Energy-dispersive X-ray (EDX) analysis of type 1 glaucony. (H) SEM photomicrographs (SE) showing the development of type 1 glaucony nanostructure from ill-defined globules/caterpillar to low packing size/density lamellar-flaky. (I) SEM photomicrograph (SE) showing type 2 glaucony nanostructure with well developed evolved flaky honeycombed-shaped structures. (J) HRTEM image showing well-defined $\sim 10 \AA$ lattice fringes of glauconite crystal and related interstratified smectitic area.
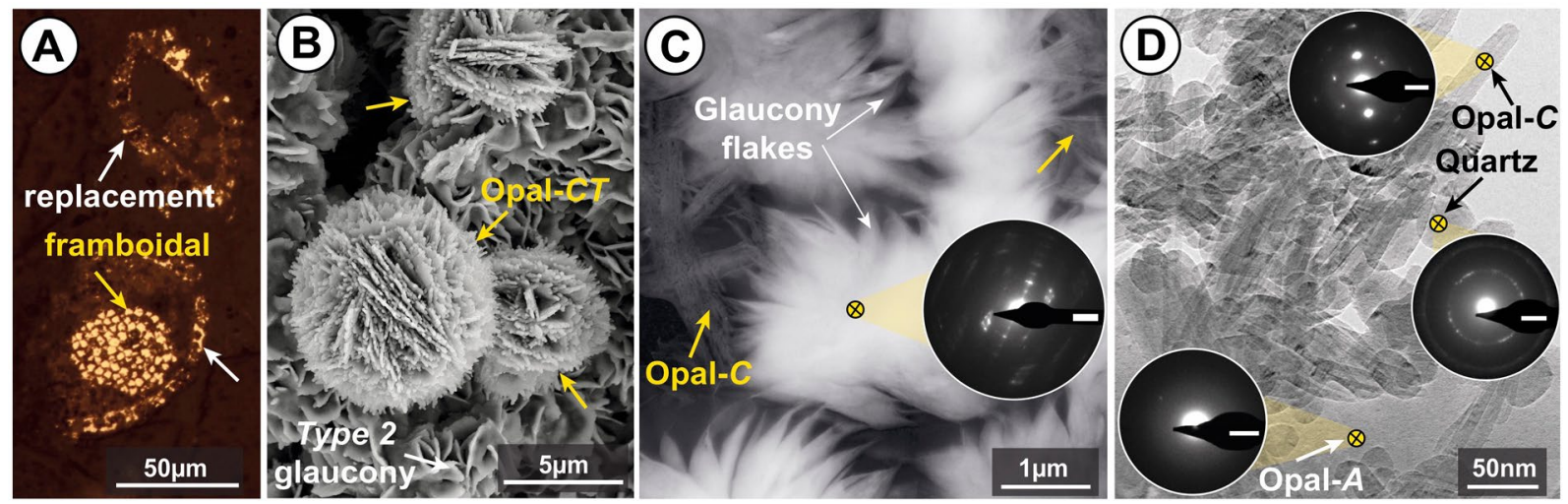

Figure 3. (A) Reflected light microscope (RLM) photomicrograph of pyrite framboids (yellow arrow) and pyritized formerly siliceous skeletons (white arrows). (B) SEM photomicrograph (SE) displaying silica lepispheres (opal-CT; yellow arrows) on the surface of type 2 glaucony. (C) High-resolution transmission electron microscope (HRTEM) photomicrograph of glaucony flakes (white arrows) and respective selectedarea electron diffraction (SAED) pattern displaying intense [001] reflections centered near $10 \AA$, and of low cristobalite (opal-C; yellow arrow). (D) Silica mineral phases under HRTEM, with their respective SAED patterns: (1) opal-A, characterized by no diffracted intensities (i.e. amorphous silica); (2) opal-C, characterized by sharp, intense (101) reflections centered $\sim 4.0 \AA$; and (3) microcrystalline quartz, depicted by (101) reflections centered near $3.3 \AA$ A. Scale bars (SAED patterns): 2 1/nm. 

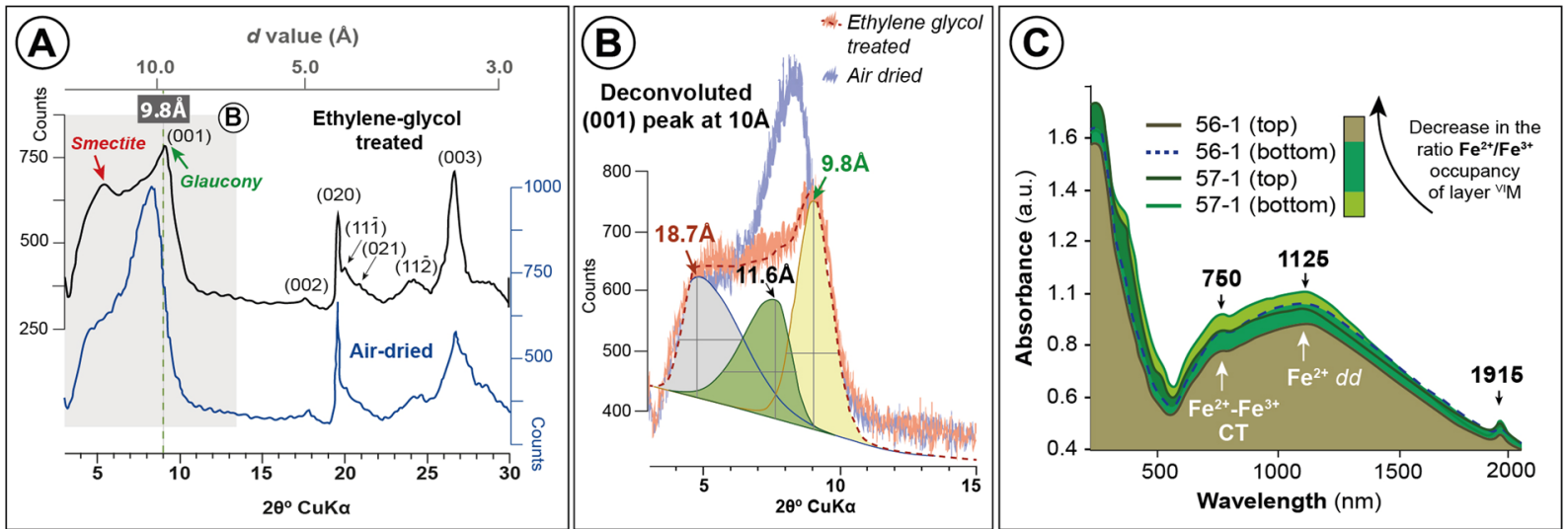

Figure 4. (A) Powder X-ray diagrams of air-dried and ethylene-glycol treated late Eocene glaucony concentrates, with indication of $d$ value. Note strong reflection at $\sim 9.8 \AA$ of smectite-poor interstratified glauconite-smectite (green arrow), and the $\sim 17 \AA$ peak of a secondary smectite (red arrow). (B) Deconvoluted (001) peak at $\sim 10 \AA$ of ethylene-glycol-treated glaucony. Smectite-poor interstratified glauconite-smectite (green arrow), and secondary smectite (red arrow) are also indicated. Note that deconvoluted green and yellow peaks (reflections at $11.6 \AA$ and $9.8 \AA$, respectively) correspond to R3 mica(0.9)/smectite (see for comparison Fig. 8.7 of Moore and Reynolds ${ }^{33}$ ). (C) UV-VIS-NIR spectra of glaucony grains from core samples $56 \mathrm{R}$ and $57 \mathrm{R}$.

\begin{tabular}{|c|c|c|c|c|}
\hline \multirow[b]{2}{*}{ Types (wt \%) } & \multirow[b]{2}{*}{1} & \multirow[b]{2}{*}{2} & \multicolumn{2}{|l|}{3} \\
\hline & & & cores & rims \\
\hline $\mathrm{K}_{2} \mathrm{O}$ & $\begin{array}{l}6.96 \\
(6.41-7.55)\end{array}$ & \begin{tabular}{|l|}
7.28 \\
$(6.58-7.86)$
\end{tabular} & $\begin{array}{l}5.80 \\
(5.24-6.39)\end{array}$ & $\begin{array}{l}5.07 \\
(4.33-5.25)\end{array}$ \\
\hline $\mathrm{Fe}_{2} \mathrm{O}_{3} *$ & $\begin{array}{l}27.02 \\
(24.31-28.08)\end{array}$ & $\begin{array}{l}27.45 \\
(26.33-29.69)\end{array}$ & $\begin{array}{l}23.62 \\
(21.40-26.57)\end{array}$ & $\begin{array}{l}20.56 \\
(17.85-23.43)\end{array}$ \\
\hline $\mathrm{Al}_{2} \mathrm{O}_{3}$ & \begin{tabular}{|l|}
2,91 \\
$(2.33-3.45)$
\end{tabular} & \begin{tabular}{|l|}
3.39 \\
$(2.75-4.68)$
\end{tabular} & $\begin{array}{l}5.23 \\
(2.95-5.98)\end{array}$ & $\begin{array}{l}5.80 \\
(4.08-6.88)\end{array}$ \\
\hline
\end{tabular}

Table 1. Electron probe microanalysis (EPMA) of the glaucony types displaying the average $\mathrm{K}_{2} \mathrm{O}, \mathrm{Fe}_{2} \mathrm{O}_{3}$ * (total) and $\mathrm{Al}_{2} \mathrm{O}_{3}$ values (wt \%). *Total Fe expressed as $\mathrm{Fe}^{3+}$. Min-max values in parentheses. For complete information of the point-by-point EPMA microanalysis see Supplementary Tables S1 and S2.

siliceous bioclasts (Fig. 3A; Supplementary Fig. S5G,H), and (b) silica minerals as amorphous silica (opal-A), lepispheres of opal-CT, low cristobalite (opal-C), and microcrystalline quartz (Fig. 3B-D). The occurrence of silica minerals is rarely observed in our SEM analysis, except for rare silica lepispheres found outside of glaucony grains (Fig. 3B). Silica particles were detected mainly by HRTEM analysis including electron diffraction (Fig. 3C,D).

XRD air-dried spectrums of paramagnetic fraction rich in glaucony grains display a slightly higher-spacing reflection than expected for pure glauconite $(\sim 10.8 \AA)$ according to the higher-order $(d 001)$ basal peaks (e.g. $(003)$; Fig. 4A). After ethylene-glycol treatment, this first basal reflection splits into various peaks, of which the highest intensity at $\sim 9.8 \AA$ spacing with a tale toward lower angles corresponds to a glauconite-smectite mixed layer ${ }^{34}$ (Fig. 4A,B). XRD data also indicates a significant secondary discrete smectite content, as evidenced by $d 001$ peak splitting at $\sim 17 \AA$ after glicolation (Fig. 4A,B).

UV-Vis-NIR color spectroscopy of glaucony grains displays gradually decreasing levels of absorbance of both $\mathrm{Fe}^{2+}-\mathrm{Fe}^{3+}$ charge transfer and $\mathrm{Fe}^{2+} d d$ absorption bands (at 750 and $1125 \mathrm{~nm}$ respectively; Fig. $4 \mathrm{C}$ ) in cores $57 \mathrm{R}$ to 56R. Furthermore, the absorption bands observed at $1915 \mathrm{~nm}$, which denote presence of $\mathrm{H}_{2} \mathrm{O}$ molecules, also decrease upward through the glauconitic horizon (Fig. 4C). Color of Fe-bearing minerals is dependent on the occurrence of $\mathrm{Fe}^{2+} / \mathrm{Fe}^{3+}$ in their structures ${ }^{35}$. Thus, color and absorption spectroscopy reveals a gradually decreasing $\mathrm{Fe}^{2+}: \mathrm{Fe}^{3+}$ ratio in the occupancy of the octahedral layer of glaucony grains (Fig. 4C; see also Fig. 10 in Sánchez-Navas et al. $\left.{ }^{36}\right)$. This corresponds to a gradually decreasing abundance of types 1 and 2 glaucony along with a slight increase in brownish-green type 3 glaucony grains upwards through the studied core (Supplementary Fig. S2B).

According to mineral chemistry analysis, type 2 displays slightly higher values in $\mathrm{K}_{2} \mathrm{O}, \mathrm{Fe}_{2} \mathrm{O}_{3}$ (total $\mathrm{Fe}$ ), and $\mathrm{Al}_{2} \mathrm{O}_{3}$ than type 1 (Table 1 and point-by-point analyses in Supplementary Table S1). Rims of type 3 grains show the lowest content of $\mathrm{K}_{2} \mathrm{O}$ and $\mathrm{Fe}_{2} \mathrm{O}_{3}$, and the highest in $\mathrm{Al}_{2} \mathrm{O}_{3}$ content compared to types 1 and 2 (Table 1 and point-by-point analyses in Supplementary Table S2). However, the values in the cores of type 3 grains range between those of the rims in the same grains and of the grains of types 1 and 2 values. The X-ray maps of $\mathrm{K}, \mathrm{Fe}$ and $\mathrm{Al}$ were constructed to show the changes in compositions between green cores and brownish areas (in the rims and cracks) (Fig. 5A; Supplementary Fig. S6 and Table S2). Brownish rims/cracks of type 3 glaucony were revealed as a Fe-bearing dioctahedral smectite (nontronite) phase according to their textural, mineral and chemical characteristics. Furthermore, HRTEM images at the core-rim contact of type 3 glaucony display significant differences of composition (Fig. 6), which is compatible with the coexistence at the nanoscale of both glaucony and nontronite. 

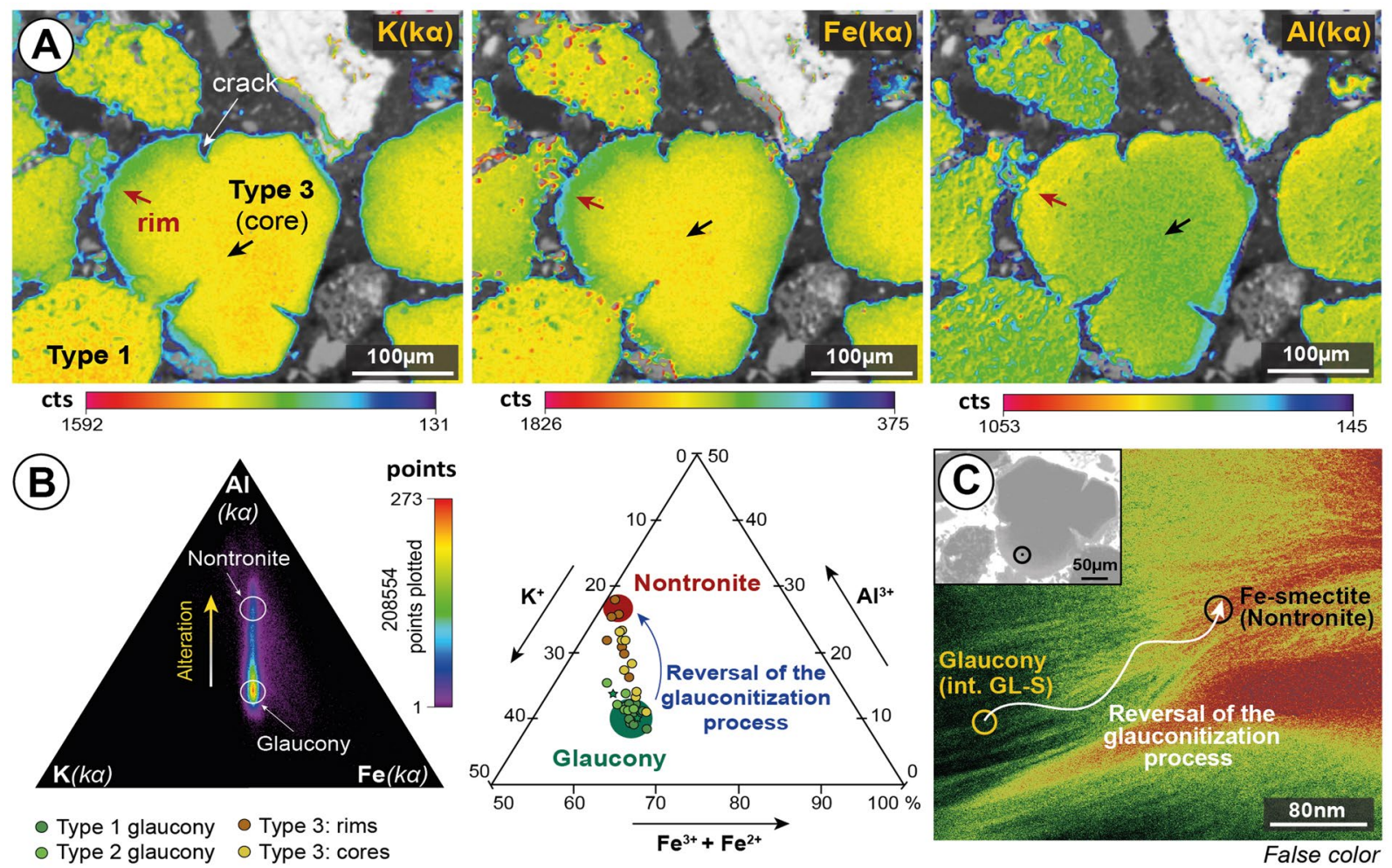

- Type 1 glaucony 0 Type 3 : rims

- Type 2 glaucony 0 Type 3 : cores Mica

Figure 5. Chemical composition obtained by electron probe microanalysis (EPMA). (A) X-ray (K $\alpha$ ) mappings showing abundances of $\mathrm{K}, \mathrm{Fe}$ and $\mathrm{Al}$ with voids, polish defects, and all other mineral phases masked out, overlain onto a grey-scale base-layer calculated with the expression $\sum[($ counts)i.Ai], (where A is atomic number, and i is $\mathrm{Si}, \mathrm{Ti}, \mathrm{Al}, \mathrm{Fe}, \mathrm{Mn}, \mathrm{Mg}, \mathrm{Ca}, \mathrm{Ba}, \mathrm{Na}, \mathrm{K}, \mathrm{P}, \mathrm{S}$ and $\mathrm{O}$ ), which contains the basic textural information of the scanned areas. Color scales represent counts (cts) with warmer colors representing more intense X-ray signals. Altered rims (red arrows) have lower $\mathrm{K}$ and Fe contents, and higher Al content relative to cores (black arrows). (B) Triangular diagrams Al-K-Fe showing the chemical domains of glaucony and nontronite. First diagram to the left corresponds to the accumulated number of pixels obtained from X-ray (qualitative) maps presented in A. The second diagram to the right corresponds to single-spot quantitative EPMA analyses (a.p.f.u.). (C) HRTEM photomicrograph showing reversal of the glauconitization process. False color image (phase map) with colors corresponding to $\mathrm{AEM}$ compositions of: interstratified glauconite-smectite, $\left(\mathrm{Si}_{3.53} \mathrm{Al}_{0.29}\right.$ $\left.\mathrm{Fe}^{3+}{ }_{0.18}\right)_{4}\left(\mathrm{Al}_{0} \mathrm{Mg}_{0.34} \mathrm{Fe}_{1.68}\right)_{2.02}\left(\mathrm{~K}_{0.77} \mathrm{Ca}_{0.03}\right)_{0.8}$ (green color), and nontronite, $\left(\mathrm{Si}_{3.73} \mathrm{Al}_{0.27}\right)_{4}\left(\mathrm{Al}_{0.30} \mathrm{Mg}_{0.41} \mathrm{Ti}_{0.03} \mathrm{Fe}_{1.30}\right)_{2.02}$ $\left(\mathrm{K}_{0.43} \mathrm{Ca}_{0.03}\right)_{0.46}$ (red color).

\section{Discussion}

Paleoenvironmental implications of glaucony maturity. The glauconitization process has been divided into four evolutionary stages according to specific morpho-textural, mineralogical and geochemical characteristics of glaucony grains ${ }^{3,31,37}$ : (1) nascent, (2) slightly evolved, (3) evolved, and (4) highly evolved. Late Eocene ODP Hole 696B types 1 and 2 glaucony are interpreted to be mature (evolved: 7\% $\mathrm{K}_{2} \mathrm{O}$; Table 1 and Fig. 7), smectite-poor interstratified $\sim 10 \AA$ glauconite-smectite (Figs 2 and $4 \mathrm{~A}, \mathrm{~B}$ ). The time required to produce an autochthonous evolved glaucony grain is considered to be higher than $10^{5}$ years for ancient glaucony-bearing records ${ }^{3}$. Whilst, Bornhold and Giresse ${ }^{10}$ estimated that recent glaucony off Vancouver Island, formed during the transgressive phase following the Last Glacial Maximum through the last $10^{3}-10^{4}$ years. We interpret the moderately sorted, irregular-shaped types 1 and 2 glaucony grains at ODP Hole 696B to have been formed in situ (autochthonous sensu Amorosi ${ }^{38}$ ), in low-energy environments. The composition and surface texture of the type 1 grains, which show less crystalline surface textures and preserve bacterial-like morphologies similar to those described in comparable glauconitized settings ${ }^{11,32}$, indicate that they are less mature than type 2. Classic microfacies criteria ${ }^{39}$ allows to establish a relationship between the winnowing of fine-grained particles, sorting and rounding of grains and the intensity of hydrodynamic processes. According to their shape, sorting and proportion of grains and matrix (i.e. glauconitic packstone texture), types 1 and 2 glaucony grains may have been episodically winnowed and exposed at the sea bottom during a period of low sedimentation rate and stratigraphic condensation lasting for a few tens of thousands years (for details see Supplementary Information and Supplementary Fig. S7). When the glaucony is immature (nascent stage sensu Odin and $\mathrm{Matter}^{31}$ ), any transport experienced by the soft, clayey pellets can result in their disaggregation. Evolved, cracked glaucony grains would be also vulnerable to mechanical breakdown into smaller, less regular fragments during physical transport or intense bioturbation. Neither grain disaggregation nor mechanical breakdown is observed in the studied sediments. The type 

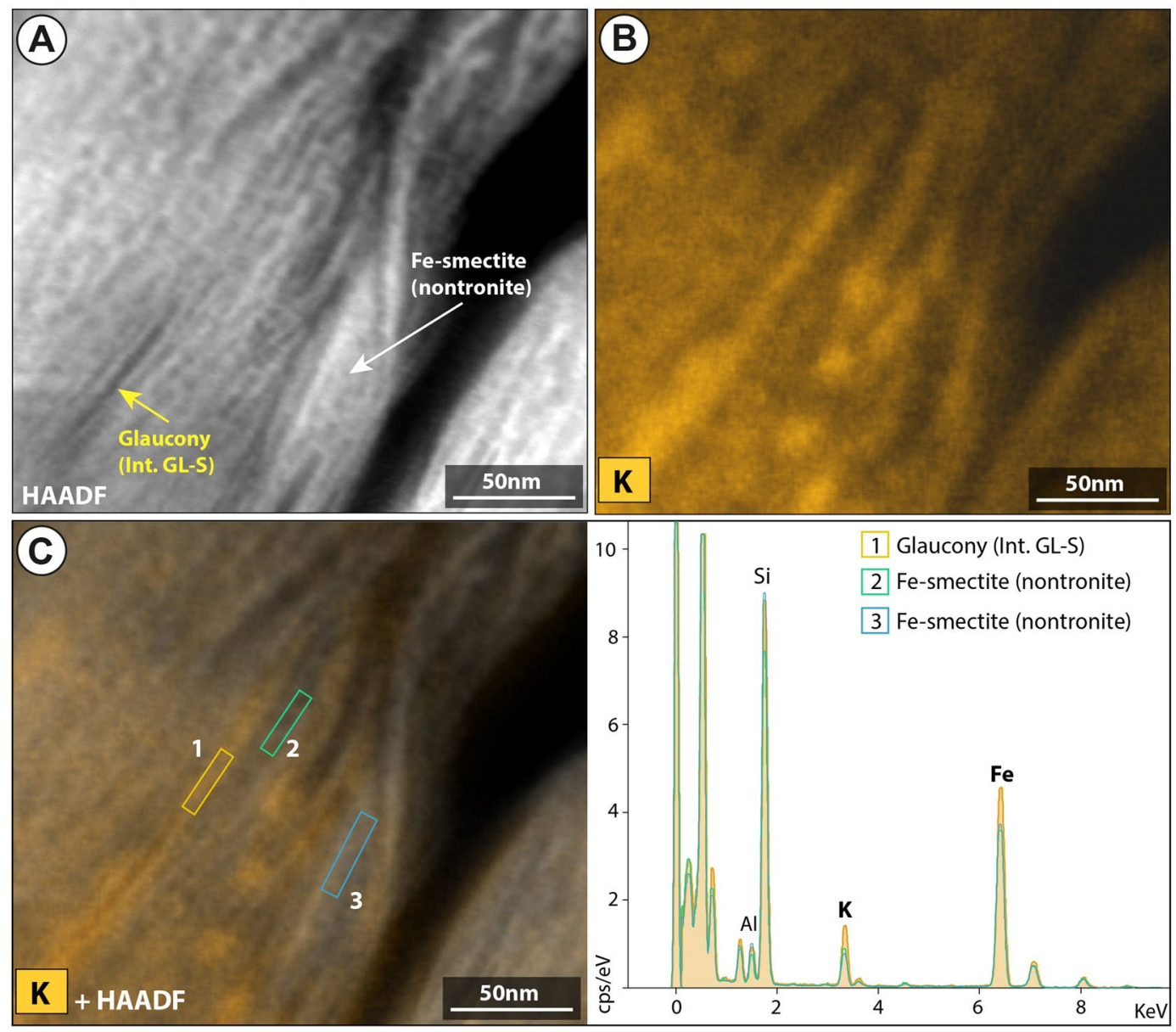

Figure 6. HRTEM EDX maps of potassium. (A) and (B) High-angle annular dark field (HAADF) STEM image and corresponding EDX map showing the distribution of K in the core-rim boundary of type 3 glaucony. (C) Combined EDX map of $\mathrm{K}$ and HAADF image with corresponding EDX spectra of the interstratified glauconitesmectite (core) and Fe(III)-smectite (nontronite rim). The yellow, green and blue boxes indicate the position of EDX analysis.

2 cracked but non-fragmented glaucony therefore indicate that grains formed in situ and that low-energy conditions prevailed during glauconitization (Supplementary Figs S4C, S5C). This implies that glaucony at Hole 696B was preserved from burial for a long time, favouring increased maturity. The abundance of mature glaucony at Hole 696B is consistent with the formation of an autochthonous condensed section, as also described at several sites in Western Europe by Amorosi ${ }^{38}$.

The real nature of glauconitized substratums is often difficult to determine. Fecal pellets are the main substrate for glaucony formation in both recent and ancient sediments ${ }^{13}$. Recent fecal pellets are documented to be produced in shelf environments $(<100 \mathrm{~m}$ water depth) by carbonate ingesting organisms including crustaceans and gastropods ${ }^{39,40}$, and contain vast quantities of undigested organic matter and clay- and silt-sized material $^{40}$. Glauconitized pellets could be interpreted as fecal pellets in origin base on their specific morphology and internal texture ${ }^{41}$. Likewise, carbonate mud (micritic) aggregates packed into burrows or accumulated at or near the surface opening of burrows can be interpreted as fecal products of invertebrate organisms ${ }^{39}$. At ODP Hole 696B, rounded- and lobate-shaped glauconitized pellets (Supplementary Fig. S4B,C), frequently filling cavities left by the burrowing activity (e.g. pellet-lined burrow Ophiomorpha; Supplementary Fig. S3C), were observed. Furthermore, pellets which can be interpreted as fecal in origin (Supplementary Fig. S3G) were observed underlying the glauconitic section (Subunit VIID of Barker et al. ${ }^{17}$ : organic-rich, sandy mudstone facies including diverse calcareous faunas; see Supplementary Fig. S3F). Therefore, macroscopic and microscopic evidences suggest that glauconitized pellets deposited at the SOM shelf are likely of fecal origin. Glauconization is thought to be concomitant with rising sea levels, as it favours the successive availability of shallower substrates to be glauconitized ${ }^{3}$. In addition it allows for decreased terrigenous inputs preventing rapid burial that would inhibit the authigenic process. A similar evolutionary pattern is envisaged in the study area between the zone of production of pellets and the zone of major glauconitization. At Hole 696B, inner- to middle-shelf (20-100 m water depth) calcareous faunas (Subunit VIID of Barker et al. ${ }^{17}$; Supplementary Fig. S3F) underlie the glauconitic section, which attest to a very shallow marine environment prior major glauconitization. In addition, Owens and Sohl ${ }^{42}$ reported that Cretaceous-Tertiary low alumina glaucony from New Jersey-Maryland Coastal Plains characterizes the middle 


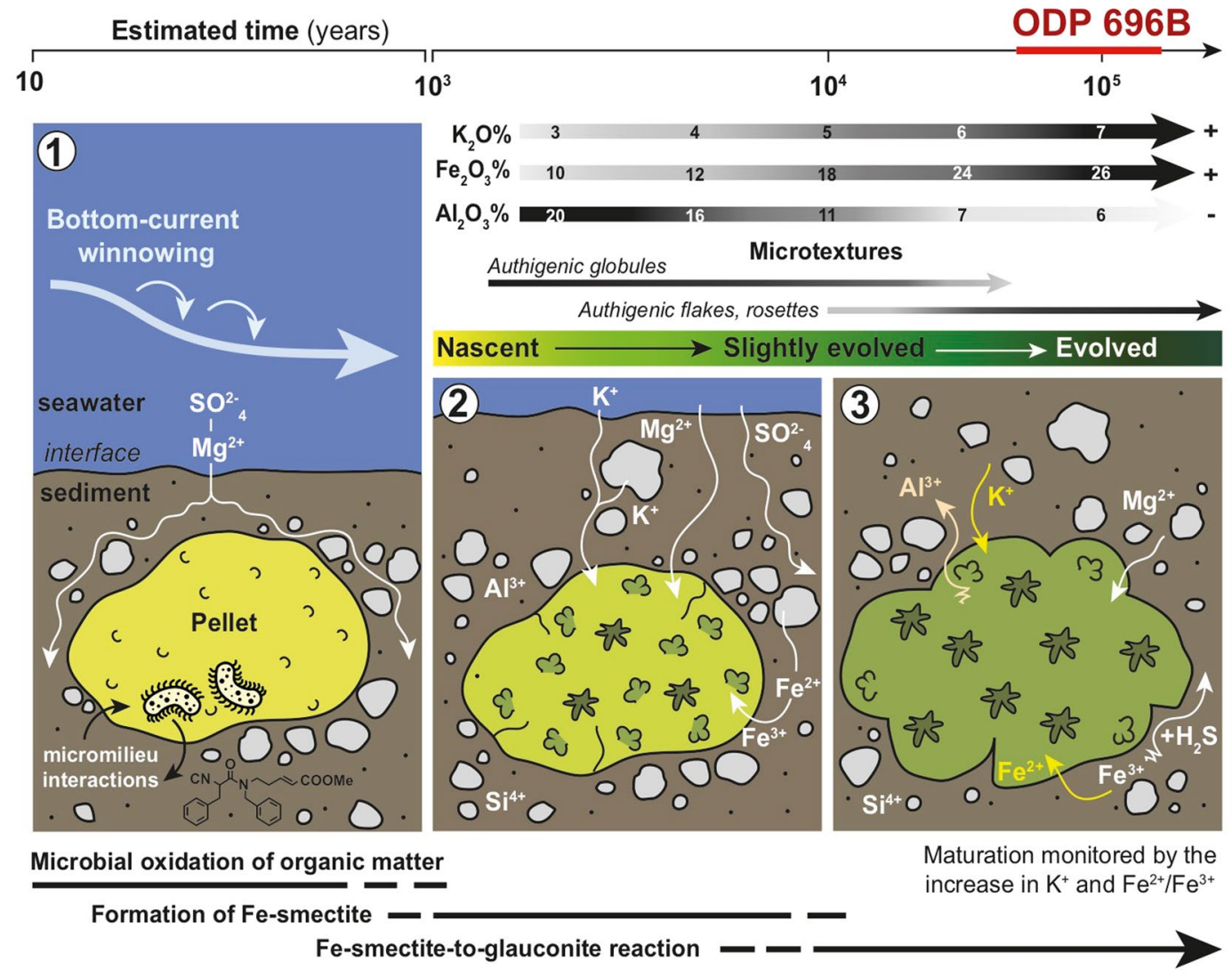

Figure 7. Model for glauconitization in the studied grains (following the ideas of Odin and Matter ${ }^{31}$; and Baldermann et al..$\left.^{6}\right)$. (1) Microbial oxidation of organic matter ( 10-10 $0^{3}$ years). (2) Neoformation of Fe(III)smectite precursor $\left(\sim 10^{3}-10^{4}\right.$ years). (3) $\mathrm{Fe}$ (III)-smectite to glauconite reaction $\left(\sim 10^{4}-10^{6}\right.$ years). Glaucony maturation involves the chemical change of $\mathrm{Si}, \mathrm{Al}^{\mathrm{VI}}, \mathrm{Mg}, \mathrm{Ca}$ and $\mathrm{Na}$ by $\mathrm{Al}^{\mathrm{IV}}, \mathrm{Fe}\left(\mathrm{Fe}^{2+}\right)$ and $\mathrm{K}$, from smectitic glauconite (nascent stage) to glauconitic mica (highly evolved stage). Microtextures also attest glaucony maturation from globules and caterpillar structures, maybe related in origin to authigenesis of clays associated with bacterial structures (cf. Eder et al. ${ }^{11}$; Zanin et al. ${ }^{32}$; Sánchez-Navas et al. ${ }^{36}$ ) to the flaky honeycombed and rosette structures typical of green clay crystals.

to outer shelf environment with depths of $>50 \mathrm{~m}$. The low Al concentrations of types 1 and 2 glaucony at Hole $696 \mathrm{~B}\left(\mathrm{Al}_{2} \mathrm{O}_{3}<10 \%\right.$; Table 1$)$ thus suggest water depths greater than $50 \mathrm{~m}$. Furthermore, the abundance, maturity and evolution of the substrates subject to glauconitization fit well with most of the described features in condensed glauconitic sections formed at the shelf-slope transition ${ }^{3}$. Therefore, a continuous sea-level rise must have occurred in order to shift the glauconitization zone over the pelleted substrate deposited in the vicinity of the SOM shelf. Hence, we infer that the sea-level rise involved an upward reduction in the supply of clastic/siliciclastic detritus during glauconitization (e.g., glaucony maturation), ultimately leading to the formation of a transgressive condensed sediment sequence (Supplementary Fig. S7).

Microscopic features and geochemistry of glaucony grains provide additional insights about the environmental conditions prevailing during its formation. Environmental quiescence and low sedimentation rates favoured the appropriate physico-chemical regime to prevail for the Fe(III)-smectite-to-glauconite reaction (glaucony maturation) to occur at ODP Hole 696B (Fig. 7). Thus, sub-oxic and moderately reducing bottom water conditions near the sediment-water interface induced shallow burial diagenesis on a glaucony-bearing bioturbated substrate (Supplementary Figs S3C,D; S4A). Furthermore, winnowing must have been active at the SOM shelf during glauconitization to stir slightly the mud-fraction and provide sub-oxygenation allowing bioturbation. Sub-oxic conditions may have favoured the rapid degradation of organic matter along with the partial dissolution of detrital clay minerals, Fe-(oxy)hydroxides, K-feldspar, bio-opal and carbonates, leading to neoformation of the $\mathrm{Fe}$ (III)-smectite precursor for glauconite (Fig. 7). The singular occurrence of mineralized spheroidal and tubular capsules (i.e. bacterial remains on type 1 glaucony; Fig. 2F and Supplementary Fig. S4D) suggests that microbial activity played some role in the formation of the Fe(III)-smectite precursor. Similar processes are reported in a modern setting of the West Pacific Ocean ${ }^{43}$. Microbial activity has also been reported in glauconite-bearing sediments formed in different geological palaeogeographic settings, such as are the Jurassic-Cretaceous condensed sections of Tethyan margins ${ }^{44,45}$ or the epicontinental Upper Jurassic Georgiev Formation of the Western Siberia $\operatorname{Basin}^{11,32,36}$. It seems likely that microbial oxidation of organic matter was critical in creating favourable redox conditions for iron fixation in the octahedral layer of nascent glauconitic structures (Fig. 7). 
The origin of the chemical elements necessary for glauconitization remains controversial. Normal seawater contains low concentrations of $\mathrm{Fe}, \mathrm{Al}$ and $\mathrm{Si}$, which do not provide favourable conditions for direct glauconite precipitation; in contrast, $\mathrm{K}$ concentrations are appreciable $\left(\sim 0.4 \mathrm{ppt}^{46}\right)$. Under these conditions, seawater is unlikely to contribute significant Fe to glauconitization but is a viable source of $\mathrm{K}$. In addition, Fe in the present-day Southern Ocean is the primary factor limiting productivity, as determined by mesoscale Fe-enrichment experiments ${ }^{47}$. Therefore, continental supply related to physical weathering of terrigenous particles rich in $\mathrm{Fe}, \mathrm{K}$ and $\mathrm{Si}$ is the most cited viable source for glauconitization in shallow marine sediments ${ }^{31,48}$. The $\mathrm{Fe}_{2} \mathrm{O}_{3}$ (total $\mathrm{Fe}$ ) content of autochthonous types 1 and 2 glaucony ( $>27 \mathrm{wt} \%$; Table 1$)$ is higher than most reported open shelf glaucony-bearing deposits ${ }^{13}$. In modern oceans, high Fe-supply sources are likewise available in high-productivity outer shelf to slope upwelling zones, where glaucony often occurs in condensed horizons ${ }^{49}$. Several pathways can supply iron to the Fe-limited Southern Ocean at the present day $^{50}$ : estuarine and groundwater inputs, shelf/ slope sediment resuspension, hydrothermalism, glacial runoff, sea-ice melt and atmospheric deposition. In the study area, we propose that the high Fe-enrichment of types 1 and 2 grains could be related to continent-derived Fe supply due to weathering of the adjacent South Orkney Islands (see location in Supplementary Fig. S2A). This enrichment can be either coetaneous to glauconitization at Hole 696B or be related to previous intense chemical weathering during Paleogene hyperthermals ${ }^{21,51}$. Alternatively, other processes could lead to the high Fe-enrichment of types 1 and 2 glaucony, such as high productivity induced by regional upwelling, or hydrothermal venting related to the Powell Ridge spreading axis ${ }^{25,26}$.

Glauconite cannot be directly precipitated at the $\mathrm{K}^{+}$concentrations available in natural pore waters, but it can gradually evolve from Fe-rich smectite (either of detrital origin or of authigenic origin and precipitated in microbial settings ${ }^{44,45}$ ), through increased interlayer charge and $\mathrm{K}^{+}$fixation due to loss of swelling layers and reduction of octahedral iron ${ }^{44}$. Localized acidification during early glauconitization (nascent stage; Fig. 7) promoted the formation of Fe(III) smectite. Acidification also favours halmyrolysis (submarine chemical alteration and/or dissolution at the sea floor), e.g. K leaching from the dissolution of biotite, muscovite and K-feldspar of the surrounding detrital sediment, which increases $\mathrm{K}$ content in pore waters. Consequently maturation of Fe-rich smectite to glauconite was triggered by $\mathrm{K}^{+}$fixation under moderately reducing (post-oxic) conditions. The irreversible $\mathrm{K}^{+}$ fixation probably favoured the evolution from Fe(III)-smectite to glauconite in the same way as the illitization of smectite does ${ }^{52}$. The acidification related to the Fe(III)-smectite formation could be buffered by calcium carbonate dissolution, which is supported by replacement of foraminiferal tests by silica, as commonly observed in the studied core section (Subunit VIIC; sensu Barker et al. ${ }^{17}$ ). Experimental work has also shown that high silica concentrations are necessary for the $\mathrm{Fe}$ (III)-smectite precursor of glauconite to form, as Fe-rich, $7 \AA$ clays (berthierine) will form instead at low silica concentrations ${ }^{53}$. The Southern Ocean, at present, plays a key role in the global production of biogenic silica ${ }^{54}$. The late Eocene witnessed also a biogenic silica radiation ${ }^{55}$, which resulted in high species diversity and enhanced Southern Ocean biogenic opal burial ${ }^{56}$. This may link glaucony formation in the SOM shelf to the presence of abundant primary bio-opal as revealed by HRTEM images (Fig. 3D).

The reported paleoenvironmental and paleoceanographic changes during and following the glauconitization process in the cores 57R-56R of the Hole 696B (ODP Leg 113) provide a window into changing conditions in the SOM from 35.5 to $34.10 \mathrm{Ma}$, just before the EOT. Further work on late Eocene glaucony deposits from around the Antarctic margin will provide new insights into potential links between the Antarctic ice sheet development and the coeval changes in the tectonic and paleoceanographic configurations.

Post-depositional alteration of glaucony at Hole 696B. The rare occurrence of type 3 glaucony, with greenish cores and altered brownish rims/cracks (Figs 2B, 5 and 6; Supplementary Figs S5D and S6) needs further explanation. The presence of zoned glauconitized grains has been explained either as a result of an alteration of glaucony (weathering) $)^{52,57}$, or as an intermediate stage of evolution from nascent to highly evolved glaucony (i.e. from glauconitic smectite to glauconitic mica $\left.{ }^{31}\right)^{1,58}$. At ODP Hole 696B, the typical textural form of glauconitic smectite found at glaucony rim-grains by $\mathrm{Odom}^{58}$ is not observed. In addition, the chemical alteration affecting type 3 glaucony is not restricted to the rims but it is also observed within the cores through cracks (e.g. Fig. 2D). EPMA point-by-point analyses of these grains indicate that $\mathrm{K}$ and $\mathrm{Fe}$ were leached from greenish mature (evolved glaucony) producing the Al-rich brownish rims and cracks (Supplementary Table S2). Brownish rims and cracks of type 3 glaucony grains are thus interpreted to form in relation to the development of a secondary, dioctahedral $\mathrm{Fe}$ (III)-smectite (nontronite) due to alteration after previous type 3 primary glaucony. This is supported by the $d 001$ peak in XRD (Fig. 4A,B), mineral chemistry (Fig. 5; Supplementary Table S2 and Supplementary Fig. S6), and the HRTEM images (Figs $4 \mathrm{C}$ and 6). Pestitschek et al. ${ }^{59}$ suggested that weathering could reverse the glauconitization process, as glauconitic minerals degrade to smectite. The observed smectitization process leading to the formation of nontronite in the rims/cracks of type 3 glaucony could result thus from subaerial weathering in soils (reversion of the glauconitization process sensu Courbe et al..$^{57}$; see also Eder et al. ${ }^{11}$ ) or as an oxidized product of the interaction with hydrothermal fluids (submarine weathering, or halmyrolysis ${ }^{60}$ ). There is no reported evidence of subaerial exposure of the SOM, but local raising along major syn-rift structures (e.g. graben/ horst-bounding faults; Supplementary Fig. S2A) could trigger subaerial weathering on rift shoulders of raised/ tilted blocks. Nontronite is common and widespread in modern hydrothermal vent areas ${ }^{5,61}$. Dredge samples from the southwestern margin of Powell Basin include middle Eocene hydrothermally-modified alkali basalts ${ }^{26}$ (Supplementary Fig. S2A), which suggest that the proto-Powell Basin could have started to open by continental extension in Eocene times. Rift-related volcanism in the proto-Powell Basin and major syn-rift structures at the SOM shelf, could have guided either subaerial weathering on tilted blocks or submarine hydrothermally triggered halmyrolysis, which would favour the alteration of previous formed glaucony grains.

Penecontemporaneous remobilization of parautochthonous (sensu Amorosi ${ }^{38}$ ) glaucony grains by waves, tides, storms or currents is common within shallow-marine to deep-water environments ${ }^{62}$. Type 3 glaucony thus 
most probably constitutes one type of intra-sequential grains that are altered (oxidized) from grains with similar characteristic to in situ type 2 glaucony. These altered grains may have been transported from nearby areas of the SOM shelf affected either by subaerial weathering or by hydrothermal vents and deposited next to in situ and non-altered grains of types 1 and 2 . An alternative hypothesis could consider alteration of type 3 glaucony grains to have been synchronous with green-clay authigenesis at Hole 696B, but neither evidences of oxidation of autochthonous types 1 and 2 glaucony nor other mineral particles or matrix have been identified. Likewise, physical characteristics of type 3 grains evidence mechanical breakdown subject to transport from their place of formation.

Further constraints: limiting factor for glauconitization. Subsequent transgression favoured burial, falling $\mathrm{O}_{2}$ levels, and ongoing reducing sulphidic conditions at Hole 696B during early diagenesis. The increasingly reducing conditions from suboxic-postoxic to sulphidic environments during deepening and sediment burial allowed enough production of $\mathrm{S}^{2-}$ in pore waters from marine $\mathrm{SO}_{4}{ }^{2-}$, which favoured the removal of $\mathrm{Fe}^{2+}$ for iron-bearing mineral precipitation. Diagenetic pyrite formed later, as revealed in petrographic and BSE images, either within the fine-grained matrix of the sediment (and often within the matrix surrounding the periphery of glaucony grains: e.g. Supplementary Fig. S5G) or infilling fissures within glaucony grains due to compaction (Supplementary Fig. S5H). Baldermann et al. ${ }^{8}$ stated that when Eh conditions within the fecal pellets micromilieu turn to low values and anoxic conditions, the green-clay forming process stops and pyrite forms. In our study site, iron-sulphide precipitation was thus a limiting factor for glauconitization by sequestration of $\mathrm{Fe}^{2+}$, as described in comparable glaucony-bearing facies ${ }^{8,11,36}$. A significant decrease in acidity of pore waters, as previously discussed, along with sediment porosity reduction and compaction with increased burial depth also favoured significant silica diagenesis at ODP Hole 696B (Fig. 3B-D). Consequently, sulphate reduction and silica diagenesis played a major role in diagenetic reactions observed throughout the glaucony-bearing facies in the studied section.

\section{Conclusions}

The integrated sedimentological, mineralogical and geochemical characterization of glaucony facies at ODP Hole $696 \mathrm{~B}$ assesses the physico-chemical conditions prevailing during glauconitization in the Antarctic late Eocene sediments. These conditions occurred in the open marine, shelf-slope transition of the SOM under sub-oxic moderately reducing conditions near to the sediment-water interface. The required environmental conditions were triggered by low sedimentation rates leading to stratigraphic condensation. Recurrent winnowing by bottom currents stirred the mud fraction slightly and provided sub-oxygenation at that site. This study represents the first well-documented case of late Eocene autochthonous, mature (evolved; $\mathrm{K}_{2} \mathrm{O}$-rich $\sim 7 \mathrm{wt} \%$ ), smectite-poor interstratified $\sim 10 \AA$ glauconite-smectite occurrence in Antarctica. Therefore, glaucony authigenesis is utilized here as a reliable paleoenvironmental indicator for Antarctic Cenozoic climate history. Glaucony authigenesis thus marks the base of a transgressive condensed sequence deposited at the SOM shelf margin during the late Eocene. Results from this work provide important new insights into changing paleoceanographic conditions during a late Eocene transgressional event, just before the EOT. Further work is needed to understand the implications of this transgression for the investigation into the growth of the continent-wide ice sheet and/or the controversial opening/deepening of the Drake Passage.

\section{Data Availability}

The datasets generated and/or analyzed during the current study are available from the corresponding author upon reasonable request.

\section{References}

1. Velde, B. \& Odin, G. S. Further information related to the origin of glauconite. Clays and Clay Minerals 23, 376-381 (1975).

2. Odin, G. S. \& Létolle, R. Glauconitization and phosphatization environments: a tentative comparison. Marine Phosphorites; Geochemistry, Occurrence, Genesis. SEPM Special Publication 29, 227-237 (1980).

3. Odin, G. S. Green Marine Clays. Develop Sediment 45 (Elsevier, 1988).

4. Giresse, P. \& Wiewióra, A. Stratigraphic condensed deposition and diagenetic evolution of green clay minerals in deep water sediments on the Ivory Coast-Ghana Ridge. Marine Geology 179, 51-70 (2001).

5. Cuadros, J., Dekov, V. M., Arroyo, X. \& Nieto, F. Smectite formation in submarine hydrothermal sediments: samples from the HMS Challenger Expedition (1872-1776). Clays and Clay Minerals 59, 147-164 (2011).

6. Baldermann, A., Warr, L. N., Grathoff, G. H. \& Dietzel, M. The rate and mechanism of deep-sea glauconite formation at the Ivory Coast-Ghana Marginal Ridge. Clay and Clay Minerals 61(3), 258-276 (2013).

7. El Albani, A., Meunier, A. \& Fürsich, F. Unusual occurrence of glauconite in a shallow lagoonal environment (Lower Cretaceous, northern Aquitaine Basin, SW France). Terra Nova 17, 537-544 (2005).

8. Baldermann, A., Grathoff, G. H. \& Nickel, C. Micromilieu-controlled glauconitization in fecal pellets at Oker (Central Germany). Clay Minerals 47(4), 513-538 (2012).

9. Huggett, J. M. \& Cuadros, J. Glauconite formation in lacustrine/palaeosol sediments, Isle of Wight (Hampshire basin), UK. Clay Minerals 45, 35-49 (2010).

10. Bornhold, B. D. \& Giresse, P. Glauconitic sediments on the continental shelf off Vancouver Island, British Columbia, Canada. Journal of Sedimentary Petrology 55, 653-664 (1985).

11. Eder, V. et al. Depositional controls on glaucony texture and composition, Upper Jurassic, West Siberia Basin. Sedimentology 54, 1365-1387 (2007).

12. Amorosi, A. The occurrence of glaucony in the stratigraphic record: distribution patterns and sequence stratigraphic significance. International Association of Sedimentologists Special Publications 45, 37-54 (2012).

13. Banerjee, S., Bansal, U. \& Thorat, A. A review on palaeogeographic implications and temporal variation in glaucony composition. Journal of Palaeogeography 5, 43-71 (2016).

14. Stickley, C. E. et al. Timing and nature of the deepening of the Tasmanian Gateway. Paleoceanography 19, No. 4 (2004)

15. Ludwig, W. et al. Site 511. Initial Reports of the Deep Sea Drilling Project 71, 21-109 (1980).

16. Porebski, S. J. Shelf-valley compound fill produced by fault subsidence and eustatic sea-level changes, Eocene La Meseta Formation, Seymour Island, Antarctica. Geology 28, 147-150 (2000). 
17. Barker, P. F. et al. Proceedings of the Ocean Drilling Program, Initial Reports, 113. Ocean Drilling Program, College Station, Texas (1988).

18. Feary, D. A. et al. ODP Leg 182 Initial Results. Proceedings of the Ocean Drilling Program, Initial Reports, College Station, TX, USA $182(2000)$.

19. McGowran, B. The Australo-Antarctic Gulf and the Auversian facies shift. Geological Society of America Special Papers 452, 215-240 (2009).

20. Houben, A. J. P. et al. Late Eocene Southern Ocean cooling and invigoration of circulation preconditioned Antarctica for full-scale glaciation. Geochemistry, Geophysics, Geosystems 20, 2214-2234 (2019).

21. Zachos, J. C., Dickens, G. R. \& Zeebe, R. E. An early Cenozoic perspective on greenhouse warming and carbon-cycle dynamics. Nature 451(7176), 279-283 (2008).

22. Miller, K. G. et al. Climate threshold at the Eocene-Oligocene transition: Antarctic ice sheet influence on ocean circulation, in Koeberl, C. \& Montanari, A., eds, The Late Eocene Earth-Hothouse, Icehouse, and Impacts: Geological Society of America Special Paper 452, 169-178 (2009).

23. King, E. C. \& Barker, P. F. The margins of the South Orkney microcontinent. Journal of the Geological Society 145, 317-331 (1988).

24. Bohoyo, F., Galindo-Zaldívar, J., Maldonado, A., Schrider, A. A. \& Suriñach, E. Basin development subsequent to ridge-trench collision: the Jane Basin, Antarctica. Marine Geophysical Researches 23, 413-421 (2002).

25. King, E. C. et al. Crustal structure and sedimentation in Powell Basin. In Geology and seismic stratigraphy of the Antarctic margin 2 (eds Barker, P. F \& Cooper, A. K.) 75-93 (American Geophys Union, 1997).

26. Barber, P. L., Barker, P. F. \& Pankhurst, R. J. Dredged rocks from Powell Basin and the South Orkney Microcontinent. In: Thomson, M. R. A., Crame, J. A., Thomson, J. W. (Eds), Geological Evolution of Antarctica. Cambridge University Press, Cambridge, pp. 361-367 (1991).

27. Wei, W. \& Wise, S. W. Middle Eocene to Pleistocene calcareous nannofossils recovered by Ocean Drilling Program Leg 113 in the Weddell Sea. In: Proceedings of the Ocean Drilling Program, Scientific Results 113, vol. 188. Ocean Drilling Program, College Station, Texas, pp. 639-666 (1990).

28. Houben, A. J. P. et al. Reorganization of Southern Ocean plankton ecosystem at the onset of Antarctic Glaciation. Science 340, 341-344 (2013).

29. Rossman, G. R. Optical spectroscopy. In Spectroscopic Methods in Mineralogy and Geology (F.C. Hawthorne, ed.). Reviews in Mineralogy 18, 207-254 (1988).

30. Robert, C. \& Maillot, H. Palaeoenvironments in the Weddell Sea area and Antarctic climates, as deduced from clay mineral associations and geochemical data, ODP Leg 113. In Proceedings of the Ocean Drilling Program (eds Barker, P. F. \& Kennett, J. P. et al.) 51-66 (Scientific Results 113, 1990).

31. Odin, G. S. \& Matter, A. De Glauconiarum Origine. Sedimentology 28, 611-641 (1981).

32. Zanin, Y. N., Eder, V. G. \& Zamirailova, A. G. Bacterial forms in glauconites from Upper Jurassic deposits of the West Siberian Plate. Russian Geology and Geophysics 45, 774-777 (2004).

33. Lynne, B. Y. et al. Tracking crystallinity in siliceous hot-spring deposits. American Journal of Science 307, 612-641 (2007).

34. Moore, D. M. \& Reynolds, R. C. X-Ray Diffraction and the Identification and Analysis of Clay Minerals: Oxford University Press, Oxford, 2nd ed., $378 \mathrm{p}$ (1977).

35. Burns, R. Mineralogical Applications of Crystal Field Theory, second ed. Cambridge University Press, Cambridge (1993).

36. Sánchez-Navas, A. et al. Color, mineralogy and chemistry of Upper Jurassic West Siberian glauconite as useful paleoenvironmental indicator. Canadian Mineralogist 46, 1249-1268 (2008).

37. Amorosi, A., Sammartino, I. \& Tateo, F. Evolution patterns of glaucony maturity: a mineralogical and geochemical approach. Deep Sea Research Part II: Topical Studies in Oceanography 54, 1364-1374 (2007).

38. Amorosi, A. Glaucony and sequence stratigraphy: a conceptual framework of distribution in siliciclastic sequences. Journal of Sedimentary Research 65, 419-425 (1995).

39. Flügel, E. Microfacies of Carbonate Rocks, Analysis, Interpretation and Application (Springer, 2010).

40. Pilskaln, C. H. \& Honjo, S. The fecal pellet fraction of biogeochemical particle fluxes to the deep sea. Global Biogeochemical Cycles 1, 31-48 (1987).

41. McRae, S. G. Glauconite. Earth-Science Reviews 8, 397-440 (1972).

42. Owens, J. P. \& Sohl, N. F. Glauconites from New Jersey-Maryland Coastal Plain: their K/Ar ages and application in stratigraphic studies. Geological Society of America Bulletin 84, 2811-2838 (1973).

43. Tazaki, K. \& Fyfe, W. S. Microbial green marine clay from Izu-Bonin (west Pacific) deep-sea sediments. Chemical Geology 102, $105-118(1992)$

44. Sánchez-Navas, A., Martín-Algarra, A. \& Nieto, F. Bacterially-mediated authigenesis of clays in phosphate stromatolites. Sedimentology 45-3, 519-533 (1998).

45. Martín-Algarra, A. \& Sánchez-Navas A. Bacterially mediated authigenesis in Mesozoic stromatolites from condensed pelagic sediments (Betic Cordillera, Southern Spain). In: Marine Authigenesis: From global to microbial (Glenn, C. R., Lucas, J. \& PrévôtLucas, L. eds), S.E.P.M. Special Publication 66, 499-525 (2000).

46. Thurman, H. V. \& Trujillo, A.P. Essentials of Oceanography. Upper Saddle River New Jersey 07458: Prentice-Hall, Inc. 527 p (1999).

47. Boyd, P. W. et al. Mesoscale iron enrichment experiments 1993-2005: Synthesis and future directions. Science 315, 612-617 (2007).

48. Peters, S. E. \& Gaines, R. R. Formation of the 'Great Unconformity' as a trigger for the Cambrian explosion. Nature 484, 363-366 (2012).

49. Cook, P. J. \& Marshall, J. F. Geochemistry of iron and phosphorus-rich nodules from the east Australian continental shelf. Marine Geology 41, 205-221 (1981)

50. Boyd, P. W., Arrigo, K. R., Strzepek, R. \& van Dijken, G. L. Mapping phytoplankton iron utilization: Insights into Southern Ocean supply mechanisms. Journal of Geophysical Research: Oceans 117, C06009 (2012).

51. Zachos, J. et al. Trends, rhythms, and aberrations in global climate 65 Ma to present. Science 292, 686-693 (2001).

52. Kaufhold, S. \& Dohrmann, R. Stability of bentonites in salt solutions: II. Potassium chloride solution - Initial step of illitization? Applied Clay Science 49, 98-107 (2010).

53. Harder, H. Synthesis of glauconite at surface temperatures. Clays and Clay Minerals 28, 217-222 (1980).

54. Tréguer, P. J. The Southern Ocean silica cycle. Comptes Rendus Geoscience 346(11-12), 279-286 (2014).

55. Rabosky, D. L. \& Sorhannus, U. Diversity dynamics of marine planktonic diatoms across the Cenozoic. Nature 457, 183-186 (2009).

56. Schumacher, S. \& Lazarus, D. Regional differences in pelagic productivity in the late Eocene to early Oligocene: a comparison of southern high latitudes and lower latitudes. Palaeogeography, Palaeoclimatology, Palaeoecology 214, 243-263 (2004).

57. Courbe, C., Velde, B. \& Meunier, A. Weathering of glauconites: reversal of the glauconitization process in a soil profile in western France. Clay Minerals 16, 231-243 (1981).

58. Odom, E. I. Microstructure, mineralogy and chemistry of Cambrian glauconite pellets and glauconite, central USA. Clays Clay Minerals 24, 232-238 (1976).

59. Pestitschek, B., Gier, S., Essa, M. \& Kurzweil, H. Effects of weathering on glauconite: evidence from the Abu Tartur Plateau, Egypt. Clays and Clay Minerals 60(1), 76-88 (2012).

60. Wilson, M. J. Smectite clay minerals. In: Sheet Silicates, Rock-Forming Minerals, vol. 3C (eds Deer, W. A., Howie, R. A. \& Zussman, J.) (The Geological Society of London, 2013). 
61. Dekov, V. M. et al. Hydrothermal nontronite formation at Eolo Seamount (Aeolianvolcanic arc, Tyrrhenian Sea). Chemical Geology 245(1-2), 103-119 (2007).

62. Miller, K. G. et al. Upper Cretaceous sequences and sea-level history, New Jersey coastal plain. Geological Society of America Bulletin 116, 368-393 (2004).

63. Elliot, D. H. Tectonic setting and evolution of the James Ross Basin, northern Antarctic Peninsula. In Geology and Paleontology of Seymour Island Antarctic Peninsula (eds Feldman, R. M. \& Woodburne, M. O.) 541-555 (Geological Society of America Memoirs 169, 1988).

\section{Acknowledgements}

This research used samples from the ODP. We thank the staff at the Gulf Coast core repository for assistance in ODP Leg 113 core handling and shipping. Funding for this research is provided by the Spanish Ministry of Science and Innovation (grants CTM2014-60451-C2-1-P and CTM2017-89711-C2-1-P, CGL2016-75679P) cofunded by the European Union through FEDER funds and RNM-208 group (Discontinuidades estratigráficas, Junta de Andalucía, Spain). We acknowledge the help of Dr. Marîa del Mar Abad, Dr. Isabel Sánchez Almazo, Dr. Miguel Angel Hidalgo, Dr. Miguel Angel Salas, and Isabel Nieto (Scientific Instrumentation Center of the University of Granada, CIC) for their help along different phases of the laboratory work. We also acknowledge the constructive comments of two anonymous reviewers that have helped to improve this paper. We wish to thank Prof. C. Hans Nelson for their constructive comments and improvement of our English, which contributed greatly toward clarification of the text. Thanks are also given to Dr. Francisco J. Lobo and Dr. Fernando Bohoyo for their helpful comments related to the study area and regional tectonics.

\section{Author Contributions}

A.L.Q. and C.E. designed the research with the advice of A.S.N., F.N. and A.M.A., A.S.N., F.N. and A.M.A. provided insights regarding green-clay authigenesis and diagenetic evolution. F.N. provided mineralogical and crystallographic input. A.S.N. and A.G.C. provided geochemical input. A.M.A. provided input with sedimentary and geological significance of the glaucony facies. D.E. and A.S. provided an Antarctic overview and petrographic input. All authors contributed to the writing.

\section{Additional Information}

Supplementary information accompanies this paper at https://doi.org/10.1038/s41598-019-50107-1.

Competing Interests: The authors declare no competing interests.

Publisher's note Springer Nature remains neutral with regard to jurisdictional claims in published maps and institutional affiliations.

(c) Open Access This article is licensed under a Creative Commons Attribution 4.0 International License, which permits use, sharing, adaptation, distribution and reproduction in any medium or format, as long as you give appropriate credit to the original author(s) and the source, provide a link to the Creative Commons license, and indicate if changes were made. The images or other third party material in this article are included in the article's Creative Commons license, unless indicated otherwise in a credit line to the material. If material is not included in the article's Creative Commons license and your intended use is not permitted by statutory regulation or exceeds the permitted use, you will need to obtain permission directly from the copyright holder. To view a copy of this license, visit http://creativecommons.org/licenses/by/4.0/.

(c) The Author(s) 2019 